\title{
The Confrontation between Desire and Morality: A Study of the Freudian Tendency in Sister Carrie
}

\author{
Xue Zhao \\ English Language and Culture Department, Teachers' College of Beijing Union University, Beijing, China \\ Liang Zhang \\ English Language and Culture Department, Teachers' College of Beijing Union University, Beijing, China

\begin{abstract}
Theodore Dreiser's Sister Carrie (1900) suffered sharp criticism at the very moment of their appearance. Most critics and readers pointed out he depicted something amoral, especially on sexual amorality. Yet, with the development of feminism, a few years later Sister Carrie was appraised as the model of 'new woman' of the late 19th century. In the light of Freudian thought, the paper will not only draw attention to the confrontation between desire and morality but also to the effects of human inner mind in the external world in
\end{abstract} \\ attempt to explore the permanent factors that influence human's actions.
}

Index Terms - psychoanalyses, id, ego, superego

\section{INTRODUCTION}

In 1900, in the American literature field, the appearance of the book, Sister Carrie aroused great attentions of the readers as well as the reviewers. During the weeks immediately following its release, both the novel itself and its heroine Carrie were bombarded with an onslaught of unfavorable reviews. All the critics sharpened their literary knives with which they dissected the lyrical depiction of a woman's developing degeneration, the amoral disposition of Sister Carrie and the lustful characters in it. The novel was regarded with the aggrandizement of sexual impurity as vulgar, unwholesome, and unholy. The public was appalled by the fact that Dreiser did not share the traditional moral ideas of America. They blasted him for his portrait of a world from which the obligations of parenthood, marriage and citizenship have been mostly withdrawn.

Ironically, only a few years later, with the emergence of women's liberation movement and the rise of feminism, attitude towards Carrie and this novel completely changed. Once regarded as amoral woman, Carrie was now appraised as the model of 'new woman' of the late $19^{\text {th }}$ century. She implied the new type of female role "with more freedom in society, more independence, more ability to run her own life without being tied to a family, or without being tied to a husband" (Donald Pizer, 1991, p. 481).

It is evident that the fundamental divergence lies in the attitude toward Carrie's implacable pursuit of desire and the way she gets it. However, due to such external factors as social background and standard of judgment, it is hard to get a fair understanding of this character. Hence, this paper intends to probe into the inner world of the heroine in light of Freudian thought, which can address itself to the point. It will start from Freud's original insight concerning "the determining force that results in the social behavior of human beings in an attempt to reveal what causes such completely different responses" (Elizabeth Wright, 1984, p.1). Through textual analysis, with the help of psychoanalysis, this paper will draw attention to the effects of human inner minds in their external world so as to explore what happens when primordial force directs into social activities which are permanent no matter whether the outside changes or not.

One area of human behaviors explored in Theodore Dreiser's Sister Carrie that has essential implication for psychoanalytic criticism is found in Carrie's constant pursuit of desire portrayed in the novel. For those who did not view the novel from a psychoanalytic perspective, what aroused the great attention of the book, is Carrie's degeneration by her unpractical desire. Through a psychoanalytic reading, however, the interest created by Carrie's experience lies not in its so-called larruping behavior---violating the social morality, but in the ways how it mirrors all the mind activities portrayed in the novel and thereby reveals a pattern of psychological behavior. This pattern is grounded in the character's fury contradiction between her id, ego, and superego---the three division of personality Freud puts which result in human behaviors and activities.

\section{TEXT ANALYSES}

A. Governed by Id: Pursue the Happiness 
Take a panoramic view of the life of Carrie. She is a piece of bait of id present from the beginning of the story on which Freud interpreted as the pleasure principle that is exerted by desire. It is the desire for true love, an ideal life, a spiritual independence, and a physical satisfaction. It pushes Carrie to act, violate the social morality, and finally change from a once bright, timid girl to a mistress of two rich men and later a person who in order to satisfy her increasingly bulged desire, discards her lover in an attempt to pursue money and happiness.

In psychoanalytic terms, desire or drives is the result of working of id in the human mind. As Freud (1949) defines in The Ego and the Id, the three different agencies (id, ego, and superego) in human minds, are the instinctual drives that spring from the constitutional needs of the body. The id situating at the lowest stratum of people's mind is in chaos. It presents the part of the human personality that strives for the satisfaction of basic needs and desires, especially the prohibited desires, for example, the desire for power, for love, for food. Here for Carrie, the id is specified as the material desire for comfort, affluent life and sexual desire for romantic love.

Driven by her pleasure principle, Carrie, from the very beginning, is described as a girl who is the younger daughter of a worker in the flour mill in the middle west of Columbia. Not satisfied with her life in hometown and desiring to gain in material things in the mysterious city, Carrie leaves her home and comes to Chicago to pursue her dream of comfort, affluence, status, and security. With the social and financial advance over the miserable narrowness that characterizes the home life of the sister with whom she has been living, Carrie begins, even more, to recognize class differences, to long for 'better' things. After a sequence of frustration, a tedious round of job-hunting and then immersion in a dreary job, Carrie keeps her dream, her desire all the time, although sometimes she has a sense of loss and depression in the swarming city. Although lonely and disappointed, she always relaxes by sitting in the rock-chair by dreaming her realized desire. She is entirely indulged into the imagination of the joy the money would bring to her. "This money cleared for its prospective possessor the way to every joy and every bauble which the heart of a woman may desire" (Theodore Dreiser 1992, p. 23). Carrie's id's pleasure principle which works strongly in her mind, has become an invisible force to her which drives her to try all means to achieve the needs or desire of her body.

Governed by the pleasure principle, the id is blind, confused and irrational. Although it is the internal agency, it often acts as a dynamic in the "psychical apparatus" and comes into being out of the body to force human beings to achieve the optimal satisfaction of its need (Jolande Jacobi, 1969, p. 145).

Therefore, enslaved by her id, which is exerted as her unpractical desire, Carrie is easy prey to Drouet who can in the first period satisfy her desire of a life free from poverty and hunger. Therefore, later, with her blind aspiration toward something more attractive, she begins to sense Drouet's limitations that can never meet her increasingly bulged desire. When she is still living with Drouet, she craves pleasure and position intensely. Drouet's friend Hurstwood, manager of a prosperous saloon, with a fine house, represents the next higher ladder of her satisfaction of drives. So, under the drive of desire which in Freud's words, the strong force of pursuit of pleasure, Carrie is again easy prey to Hurstwood who belongs to a higher social class than Drouet. In Carrie's view, Hurstwood represents power, wealth, and joy that poor Carrie cannot actually conceive but constantly desires. Hence, Carrie who dreams of happiness she may never feel, longs simultaneously for that "peace and beauty which glimmered afar off' and that radiance of delight which tints the distant hilltops of the world" (394). At last, she remains a drifting dreamer crippled by incompatible impulses that is indeed her id, which she exhibits from the very early in the novel.

\section{B. Function of Superego: Confined by Morality}

Appalled by Carrie's crazy for her desire and the consequent actions she does which result from the drive of id, readers also sense she is not totally free from the morality, which is inherited, in her mind as superego. Superego is the representative of parental and social influences upon the drives, rather than an external agency. It is in direct opposition to the id, the pleasure principle. It determines which desires or the id will contain. Therefore, it is also called cultural taboos. Since human beings cannot be very isolated from society, the influences of social moralities and conventions are strongly inherited in our mind exerted by the superego. It can be well-proved by the situation when Carrie is continually in the conflict between morality and desire.

When Carrie decides to perpetrate something violating the common moral law, she is often in two minds struggling in individual desire and morality. For example, when she first meets Drouet in the house he rents for her which symbolizes she will be the mistress of him, she is attracted by the comfort, cozy place; she seems to have realized her dream. However, when she looks at the mirror, finding the beautiful self, she hesitates and wavers. There, she hears a different voice, with which she argues, pleads and excuses. "It was not just and sapient counselor, in its last analysis. It was only an average little conscience, a thinking which represented the world, her past environment, habit, convention, in a confusing way" (Theodore Dreiser 1992, p. 80). It is the function of the superego that reminds Carrie of the moral principles, and always confines her id for pursuing unpractical happiness. The two selves --- the id-driven Carrie and the moral-fettered Carrie argue and debate all the time.

\section{Mediation of Ego: Balance the Desire and the Moral Law}

These constant conflicts in Carrie's mind reveal another psychological phenomenon in human minds that is the mediation of ego. According to Carl Gustav Jung, the human mind is the center of confliction forces beginning in childhood and following a developmental course throughout an individual's life (Jolande Jacobi, 1969). His words reveal the interplay of forces within the mind. The three personalities are not isolated but interacted. Besides the id, 
which pursues the pleasure principle, in the human mind, superego represents the individual's moral orientation. Mentioning the id and superego, Jung stated, the self in the course of its life experience (but particularly in middle life) struggling on the one hand with images of absolute pleasures, on the other hand with the demands made by social norms (Anna Freud, 1966, p. 33). Then usually the superego and the id are always in the state of confrontation. It can be shown by Carrie's self-debates in her all life which explains why Carrie cannot do everything at will without any hesitation because there are social influences exemplified as morality inherited in her mind.

The role in mediating the antagonism between id and superego is ego, which attempts to balance the desire which id arises and the moral law. The body interacts with the external environment while the "ego" mediates the actions of the body so as to achieve the optimal satisfaction of its needs. Indeed, it is the combat of the reality principle and the pleasure principle, in which the body has to obey the social demands by postponing pleasure and enduring a degree of unpleasure. It is what ego supposed to do. In Carrie, although when her id for desire bulges, her superego's morality does function to warn her "you shouldn't". Her ego indeed executes its task to mediate the antagonism. These can be shown by Carrie's sex desire and sex selection, desire and moral bond through her story, which indeed reflects the bout between id, ego and superego.

Carrie at her first meet with Hurstwood is attracted by his elegant appearance. She feels she is pleasure with him in the immediate thing and is thoroughly impressed. She never comes in contact with such grace (Theodore Dreiser 1992 , p. 75). The virile man who is with a cosmopolitan charm kindles her desire. "She is delicately molded in sentiment, and answers with vague ruminations to certain wistful chords. They awake longing" (Theodore Dreiser 1992, p. 77). As a poor girl living by the friendly aid of others, her first demand is undoubtedly for material sufficiency, yet her desire for a lover has been embedded in her heart. Though she sees comparatively little of Hurstwood, she always keeps in mind of him by one thing and another, principally by the strong impression he has made (Theodore Dreiser 1992, p. 87). She feels his glance is as effective as the spoken word of a lover. Here Carrie's superego functions. It tells her she must not secretly make a connection with another man while living with Drouet. The mediation of successful ego works. Thus, Carrie keeps her surging feelings and desires in silence. At the thought of Drouet's help and kindness, she exclaims, "you mustn't" when Hurstwood touches her hand. She finds herself is affected by a feeling of trouble and shame. She thinks, "I am getting terrible. I don't seem to do anything right" (Theodore Dreiser 1992, p. 90). The sense of morality promotes her to refuse and to introspect. When the initial desire is aroused, Carrie is hesitant. Facing lust and morality, struggling between id and superego as well as ego, she wanders and chooses.

Later, Carrie's initial desire gradually develops into a more throbbing one, which reflects Freud's view that the id is the great reservoir of libido and always drives people to be amoral. At the same time the superego plays the role of controlling the lust. Strong desires she holds, she is still deep in the struggle between sexual selection and traditional morality.

The conflict of desire and morality, or id and superego, makes ego to mediate it. The result is to bring Carrie spiritual solitude. It seems that it is Hurstwood who first lures Carrie. Yet Carrie's longing for such a graceful lover is an unproblematic fact. The perfect impression Hurstwood gives her sets the basis of her developing desire. Hurstwood's great strength, high position and rich clothing all appeal to her. Pleasure principle, like a catalytic agent, pushes her to do as she expects. Her failure in sensing love from the husband or benefactor urges her to seek real lovers who can gratify her both physically and spiritually. Carrie, to some extent, is too indulgent with herself on sexuality. Her desire for love is greatly influenced by the social status and wealth of men.

Nevertheless, when she yields sufficiently to Hurstwood, she gives thought to Drouet, and her sympathies are for the first aroused. She even looks for something that would calm her conscience (Theodore Dreiser 1992, p. 101). Here, Carrie is not overwhelmed by desire. One element of the superego---conscience, is still there in her greedy mind.

Dreiser writes in Sister Carrie among women there is a bias towards affection, a craving for the pleasure of being loved frequently exist. The longing to be shielded, bettered, sympathized wish, is one of the attributes of the sex (Theodore Dreiser 1992, p. 161). As women who are in great need of true love in their lives, the desire for ideal passion is understandable in some sense. Besides, Carrie never abandons the morality principle. The two folds of a person's superego, shame and guilt accompany them all the time and the struggle between sexual desire and moral code never end in their hearts.

For Carrie, Hurstwood adds sunshine for her joyless loves. Her temporary attachment to Drouet reflects Freud's view that sexual instinct (part of id) is in two folds, one for gratification and the other for survival (Arthur L.Caplan, 1984, p. 206). In order to pursue sexual satisfaction, Carrie yields to Drouet mostly for living.

Carrie's attachment to Drouet is moved by her desire for survival and a better life. She has strived and attempted to realize her ideals but in vain. Just at the very moment, she is in the depression of joblessness, Drouet appears. In first glance, Carrie beholds him and feels he is radiant. For her, he is the symbol of sunshine and good-humor. She finds there is a strange tie of affection drags her to him, and she has the kindliest feelings for him in every way. However, Carrie is not merely lured by Drouet's expensiveness. She is other deterred by conscience. She thinks she owes something to Drouet. Every time Drouet provides aids, she would hesitate for a while. Her wandering between the lust and moral consciousness indicates that she is not thoroughly controlled by instinctive desire.

In the whole life of Carrie's conflicting life, her id, superego and ego are always contradicting each other. 


\section{INFLUENCES OF THE THREE PERSONALITIES}

The result that Carrie is regarded as immoral is only because, in the psychoanalytic lens, her id-driven desire is so strong to confine. Whenever her id wants to bind over the bondage of superego, the ego tries to control and mediate the differences. Yet, the id for the better life and romantic love is too strong, which can bound up with certain conventions and moral, continuously push Carrie to unconsciously combat against the counterforce exerted by ego. So, at the time when the id's energy is too strong to confine, it can liberate the self in its efforts to achieve pleasures and avoid unpleasures. Briefly speaking, although the ego is seen as in part constructed from the instinctual energies, it connives with them as much as it controls them. The energies (id) are also operative in the superego, particularly in their destructive form aggression upon ego. Therefore, the censorship of the ego can be subverted, when the ego cannot efficiently repress the id's desire, and the drives or wishes can get out and become the dominant force that controls human minds.

Therefore, it is easily inferred that Carrie becomes so desire-dominated girl who can sacrifice her virtue and credit to seek for the desire she possesses for the time and upgrades frequently. In the novel, Dreiser expresses, "In Carrie, as in how many of worldlings do they not, instinct and desire, were at war for the mastery; she followed whither her craving led. She was as yet more drawn than she drew" (Theodore Dreiser 1992, p. 73-74).

However, pleasure is never wholly or finally achievable. As Freud pointed out, the id can provide both the direction and motivation to accomplishment, but too strong; it can destroy the human being. Since the mind is in a completely structured system, although the id can bound the superego and overwhelm ego for some time, it cannot always be. Finally, the ego balances and gives the final judgment of the conflicts between the id and the superego that is exerted by the reality (Frank J. Sulloway, 1979, p. 93). For Carrie, her fate is greatly influenced or dominated by the pleasure principle id and restrained by the moral principle superego.

Yet at last, it is the reality that guides her way of life. The solidarity of Carrie is just under the control of reality; the dream of perfect enjoyment is disillusioned. She feels lonely; there is little to do. Finding nowhere to go, she is peculiar, lonely, and self-withdrawing, temperamental and void.

\section{CONCLUSION}

Similar to Carrie, in our real life, we often wander between pleasure and ethic controlled by id and superego, and finally are mediated and judged by the real ego.

The psychoanalytic approach reveals a much different aspect of judgment, the one ordinarily associated with Sister Carrie. As the novel illustrates, Carrie's rise-up and fall-down is the stage upon which all of our invisible psychological conflicts are dramatized, repeatedly, day and night. Indeed, it is the incessantly mechanical function that deducts ourselves' inner world that always conflicts and balances.

Whether it intends to do so or not, Sister Carrie is created not as a degenerated woman who corrupts public morals or a model 'new woman' who dares to break the moral bond. Instead, she is vividly created as an actual human being who is often controlled by desire (id), and conflicts in the desire and morality and reality.

\section{REFERENCES}

[1] Caplan, Arthur L. \& Bruce Jennings (eds.). (1984). Darwin, Marx and Freud: Their Influence on Moral Theory. New York: Plenum Press.

[2] Dreiser, Theodore. (1992). Sister Carrie. Beijing: Foreign Learning and Researching Publishing House.

[3] Freud, Samuel. (1949). The Ego and the Id. London: The Hogarth Press Ltd.

[4] Freud, Anna. (1966). The Ego and the Mechanisms of Defenses. New York: International UP.

[5] Jacobi, Jolande. (1969). The Psychology of C. G. Jung: An Introduction with Illustrations. London: Routledge \& Kegan Paul.

[6] Pizer, Donald. (1991). Sister Carrie: An Authoritative Text, Background and Sources, Criticism. New York: W.W. Norton \& Company.

[7] Sulloway, Frank J. (1979). Freud, Biologist of the Mind: Beyond the Psycho-Analytic Legend. London: Andre Deutsch.

[8] Wright, Elizabeth. (1984). Psychoanalytic Criticism: Theory in Practice. London: Routledge.

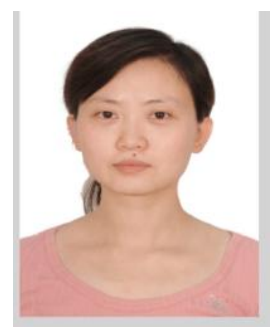

Xue Zhao was born in Tianjin, People's Republic of China in 1979. She received Master Degree of English Language and Literature from Beihang University in 2004, specialized in American literature.

From 2004, she has worked as an English Teacher at Teacher's College of BUU in Beijing. Currently she is an associate professor there. She has published several coursebooks and books in the field of American literature: Selective Readings of American Literature in $20^{\text {th }}$ century (Shanghai, China: Tongji University Press, 2018), Study of Deconstructive and Constructive Techniques and Functions in the Novels of Kunt Vonnegut (Shanghai, Donghua University Press, 2014), The Oedipus Paradox: Study of Paternal Characters and Authority in the Novels of John Irving (Shanghai, Donghua University Press, 2013). Her research interests and publications cover the areas of American Literature and TESOL, particularly Modern American Literature and the teaching of Chinese as a second for normal students. 


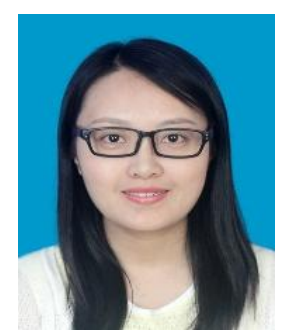

Liang Zhang was born in Henan Province, People's Republic of China in 1981. She finished her MA in English Language and Literature in Wuhan University, China in 2006.

She is currently an associate professor of Teachers' College of Beijing Union University. She has taught intensive English and advanced English for nearly ten years, and won quite a number of prizes in teaching competitions. She has also supervised a large number of BA dissertations in literature. Her major research interests are TESOL and British \& American literature. 